\title{
MODEL PENGEMBANGAN STRUKTUR DAN BAHAN PADA ELEMEN TIANG/KAKI (SUPER STRUCTUR) PADA PERMUKIMAN RUMAH TRADISIONAL BUGIS MAKASSAR DI KAWASAN PESISIR KOTA MAKASSAR
}

\author{
M.Awaluddin Hamdy ${ }^{1}$, Arman Setiawan ${ }^{2)}$ \\ 1)Jurusan Teknik Arsitektur, FakultasTeknik, Universitas Bosowa \\ Email:awal45_hamdy@yahoo.com \\ 2)Jurusan Teknik Sipil, FakultasTeknik, Universitas Bosowa \\ Email: arman_c97@yahoo.com
}

\begin{abstract}
ABSTRAK
Rumah tradisional sebagai salah satu warisan budaya, yang dikembangkan oleh masyarakat berdasarkan local genius dan local wisdom yang dimiliki oleh masyarakatnya. Penelitian yang dilaksanakan oleh Tim Peneliti dari Fakultas Teknik Universitas Bosowa Makassar di kawasan pesisir Kota Makassar, menitikberatkan pada masalah stuktur rumah tradisional Suku Bugis Makassar yang berada di wilayah perairan. Pertanyaan penelitian ini meliputi tiga hal, yakni : (1) Konstruksi rumah masyarakat suku Bugis Makassar tidak lagi mempertahankan bentuk struktur dan arsitektur tradisionalnya; (2) Penggunaan kayu ULIN (eusideroxylon zwageri) untuk material komponen kaki/tiang rumah suku Bugis Makassar tidak bisa lagi dipertahankan, mengingat ancaman kepunahan jenis kayu ULIN; (3) Belum ada material alternatif untuk material kaki/tiang rumah suku Bugis Makassar.

Tujuan penelitian ini adalah memberikan informasi dalam bentuk (1) Diskripsi evaluatif terhadap sistem konstruksi pada komponen super-struktur dan kerangka kuda-kuda rumah suku Bugis Makassar; (2) Diskripsi kuantitatif karakteristik material kayu ULIN sebagai bahan struktur tiang/kaki rumah tradisional suku Bugis Makassar; dan (3) Diskripsi visual dalam bentuk pradesign material alternatif untuk elemen tiang/kaki rumah tradisional suku Bugis Makassar. Sedangkan output yang diharapkan dari penelitian ini: (1) Desain pengembangan sistem konstruksi superstruktur dan rangka kuda-kuda rumah tradisional/vernakular suku Bugis Makassarj; (2) Karakteristik kayu ULIN secara detail, yang meliputi sifat fisis dan sifat mekanis.

Pengambilan data dalam penelitian ini dilaksanakan dengan menggunakan metode purposive dalam pemilihan sampel kayu untuk uji laboratorium, dan metode phenomenologi/naturalistik dalam pengambilan informasi tentang typical struktur original dan perkembangan bentuk dari rumah tradisional suku Bugis Makassar. Analisis data hasil pengamatan dilakukan dengan analisis kuantitatif untuk data numerical hasil uji laboratorium, dan analisis kualitatif untuk data hasil pengamatan lapangan. Hasil penelitian ini di harapkan dapat di peroleh: (1) Bentuk-bentuk model pengembangan struktur dan konstruksi bangunan rumah tradisional suku Bugis Makassar pada kawasan tepi air, (2) Inovasi baru untuk struktur tiang dan kaki (super structur) pada rumah tradisional Bugis Makassar kawasan tepi dan atas air.
\end{abstract}

Kata Kunci: Model, Struktur, Permukiman, Pesisir

1. PENDAHULUAN

Indonesia dikenal sebagai negara kepulauan dengan lebih dari $60 \%$ wilayahnya merupakan area perairan. Kondisi geografis tersebut menjadikan kawasan 
permukiman/perumahan berada di area daratan (baik dataran tinggi maupun dataran rendah), area tepi air (perumahan nelayan dan pesisir) serta area di atas air/perairan (baik perairan sungai, danau, laut/rawa).

Di antara ketiga area kawasan perumahan tersebut, masing-masing memiliki karakteristik dan permasalahan yang berbeda-beda. Dibandingkan dengan kawasan perumahan di area daratan, maka kawasan perumahan tepi air, khususnya perumahan nelayan serta kawasan perumahan di atas air / perairan relatif tertinggal dalam penanganannya.

Keberadaan kawasan perumahan tepi air tersebut banyak terdapat dan tersebar di hampir seluruh pulau di Indonesia, begitu pula dengan kawasan perumahan di atas air / perairan, kecuali Jawa.

Perumahan di atas air/perairan di Indonesia pada dasarnya berakar pada faktor-faktor geografi dan sejarah selama berabad-abad. Pada jaman dahulu, dimana transportasi air dimanfaatkan secara intensif dan penyediaan air baku untuk kebutuhan rumah tangga masih diperoleh dari sumber secara langsung, maka perumahan berkembang pesat di sekitar jalurjalur perairan, seperti sungai, danau dan laut. Pada perkembangan selanjutnya, perumahan di atas air masih menjadi alternatif permukiman. Gejala tersebut diduga dapat terjadi karena:

a) merupakan kawasan alternatif permukiman kota bagi kaum urbanis miskin.

b) merupakan peluang bagi kemudahan transportasi.

c) menjadi pintu gerbang alami untuk perdagangan antar tempat yang terpisahkan oleh badan air (laut, sungai dan danau), yang memanfaatkan transportasi air.

Kayu bukan hal yang asing di telinga kita. Kayu telah dimanfaatkan untuk memenuhi kebutuhan manusia. Berbagai pemanfatannya telah membantu kehidupan sehari-hari. Kayu Ulin atau biasa di kenal di daerah Sulawesi Selatan dengan sebutan kayu Sappu banyak di gunakan oleh masyarakat tradisional yang bermukim di daerah pesisir atau kawasan atas air sebagai tiang atau penopang rumah. Jenis kayu ulin ini banyak di jumpai di daerah Kalimantan dan Sulawesi. Karena mempunyai kekuatan dan ketahanan terhadap air sehingga banyak di gunakan sebagai tiang rumah baik di daratan maupun di perairan.

Salah satu wilayah pesisir yang penting secara ekonomi dan ekologi adalah wilayah pesisir Kota Makassar. Wilayah ini merupakan wilayah pesisir yang memiliki ciri pemanfaatan beragam dan berkaitan satu sama lain. Di wilayah ini terdapat kegiatan ekonomi yang berbasiskan sumberdaya alam seperti perikanan, pelabuhan, permukiman dan pariwisata bahari.
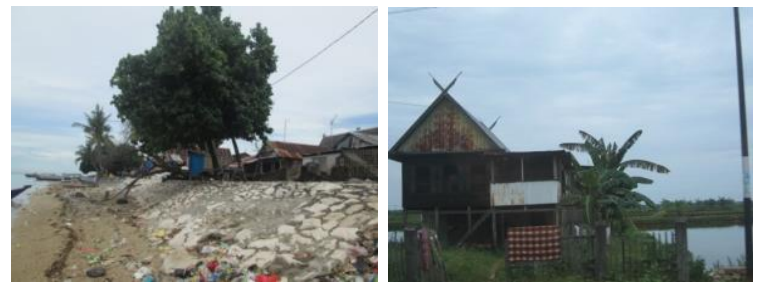


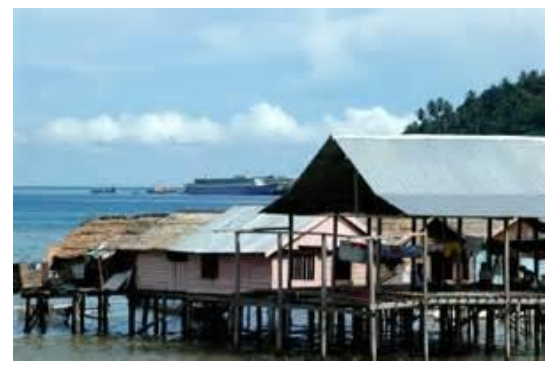

Gambar 1. Eksisting Permukiman Masyarakat tradisional kawasan pesisir

Kota Makassar merupakan salah satu kota pesisir yang ada di Indonesia yang memilki garis pantai sepanjang $32 \mathrm{~km}$ dan mencakup 11 pulau-pulau kecil dengan luas keseluruhan mencapai $122.370 \mathrm{Ha}$ atau sekitar 1,1\% dari luas wilayah daratannya. Fakta tersebut menjadikan Kota Makassar memiliki berbagai keunikan sebagai kota pesisir.

Kawasan pesisir Makassar mengalami degradasi daya dukung lingkungan yang cukup significant yang diakibatkan oleh adanya pemanfaatan ruang yang kurang terkendali dari kegiatan pembangunan serta kondisi geomorfologi kawasan pesisir yang rawan terhadap resiko bencana. Kondisi kawasan pesisir tersebut jika tidak diatasi/diperbaiki dan dimitigasi akan mengakibatkan kerusakan lingkungan pesisir yang juga akan berdampak pada daerah disekitarnya. Perencanaan kawasan pesisir ini perlu ditangani dengan cara mengembangkan konsep mitigasi bencana melalui pendekatan Zonasi yang tepat dengan mempertimbangkan tingkat resiko dan karakteristik kawasan pesisir kota Makassar.

Bertitik tolak dari uraian di atas dan tanpa meninggalkan nilai-nilai lokal suku Bugis Makassar di perairan pesisir kota, maka penelitian ini dilakukan untuk mencoba mengidentifikasi model struktur dan bahan bangunan rumah suku Bugis Makassar, berdasarkan local wisdom dan local genius yang berkembang dalam kehidupan masyarakat suku Bugis Makassar.

\section{KAJIAN LITERATUR}

2.1. Karakteristik Kawasan Pesisir dan Tepi Air

Indonesia dikenal sebagai negara perairan terluas, yaitu berwilayah laut teritorial pesisir dan laut seluas 5,7 juta km2; ditambah luas lautan dari kesepakatan Zona Ekonomi Eksklusif (ZEE) yang mencapai 2,7 juta km2 dan memiliki banyak pulau. Selain itu, juga merupakan pusat keanekaragaman hayati laut tropis terkaya di dunia.Ini disebabkan hampir 30 \% hutan bakau dan $30 \%$ terumbu karang hidup di perairan Indonesia.

Indonesia juga terkenal dengan banyaknya pulau yang dimiliki. Hingga kini tercatat terdapat 17.508 pulau dengan garis pantai sepanjang kurang lebih $81.000 \mathrm{~km}$. Dengan garis pantai sepanjang itu, maka banyak orang Indonesia memilih bermukim di daerah pesisir. Hingga kini tercatat 140 juta atau sekitar $60 \%$ penduduk Indonesia tinggal di wilayah dimaksud, yaitu di pesisir lautan dan tepi air. Bermukim di antara mangrove dan terumbu karang. Bahkan di pesisir utara Jawa, terdapat 600.000 nelayan yang menggantungkan hidupnya dari laut di sekitar tempat dimaksud.

Berkaitan dengan hal dimaksud, pengembangan perumahan dan permukiman di kawasan pesisir dan tepi air, merupakan bagian penting dalam menunjang pembangunan 
kawasan pesisir dan tepi air yang berkelanjutan; dan meningkatkan kesejahteraan bangsa Indonesia, serta masyarakat pesisir dan tepi air pada khususnya. Kawasan pesisir dan tepi air berpotensi besar merupakan faktor penting yang dapat meningkatkan perekonomian bangsa.

Pada negara- negara maju maupun berkembang, aktivitas perkonomian di wilayah pesisir dan tepi air sangat dominan dan diikuti dengan pertumbuhan jumlah penduduknya. Hal ini berdampak langsung pada sektor perumahan dan permukiman. Di Indonesia masih banyak daerah perumahan dan permukiman penduduk yang berada pada wilayah pesisir dan tepi air, yang berkondisi tidak tertata dengan baik, terlampau padat, kumuh dan tidak layak huni.

\subsection{Permukiman pada Kawasan Pesisir/Pantai}

Perumahan di atas air/perairan, dimana kawasan pesisir termasuk di dalamnya pada dasarnya berakar pada faktor-faktor geografi dan sejarah selama berabad-abad. Pada jaman dahulu, ketika transportasi air dimanfaatkan secara intensif dan penyediaan air baku untuk kebutuhan rumah tangga masih diperoleh dari sumber secara langsung, maka perumahan berkembang pesat di sekitar jalur-jalur perairan, seperti sungai, danau dan laut. Pada perkembangan selanjutnya, perumahan di atas air masih menjadi alternatif permukiman. Gejala tersebut diduga dapat terjadi karena (Balai PTPT Denpasar 2009):

a) merupakan kawasan alternatif permukiman kota bagi kaum urbanis miskin.

b) merupakan peluang bagi kemudahan transportasi.

c) menjadi pintu gerbang alami untuk perdagangan antar tempat yang terpisahkan oleh badan air (laut, sungai dan danau), yang memanfaatkan transportasi air.

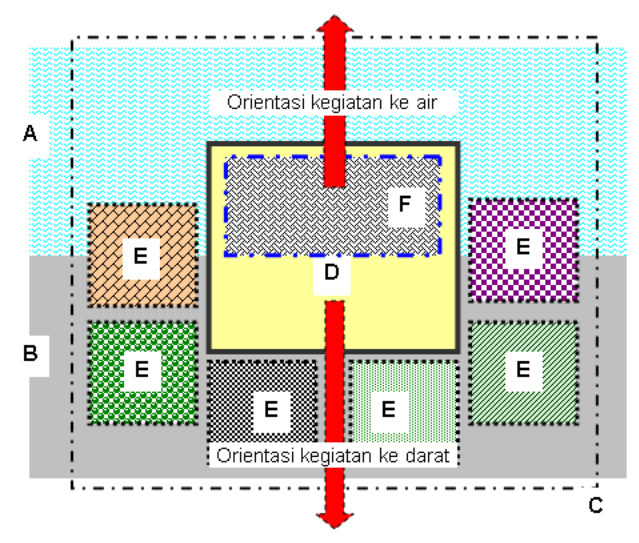

Keterangan :

A. Perairan (Sungai/Laut/Danau)

B. Daratan

C. Kawasan Tepi Air

D. Kawasan Permukiman di Tepi Air

E. Kawasan-kawasan lain di Tepi Air (Perdagangan, Pendidikan, dll)

Secara ilustratif, tahap-tapah perkembangan dan struktur spasial permukiman di kawasan atas perairan dapat dilihat pada gambar di atas. Dalam gambar tersebut, terlihat bahwa kedudukan perumahan di atas air sebagai bagian tak terpisahkan dari kawasan tepi air 
(baik di darat maupun di atas badan perairan). Dengan adanya limitasi faktor topografi dan geologi pada umumnya, maka perkembangan perumahan di atas air cenderung ke arah darat. Hal ini dipengaruhi pula oleh semakin kuatnya magnit penarik (daya tarik) kegiatan di darat, seperti industri, perdagangan, jasa dan transportasi.

Meskipun demikian, bukan berarti kegiatan di atas air berkurang dan eksistensi perumahan di atas air semakin hilang. Tetapi intensitas kegiatan malah semakin bertambah, terutama di kawasan yang berdekatan dengan pelabuhan/dermaga dan transportasi air (laut/sungai) dan jumlah rumah di atas air semakin bertambah.

Eksistensi historis perumahan/permukiman tepi air (khususnya nelayan) dan perumahan/permukiman di atas air dapat dibedakan atas 2 (dua), yaitu :

a. Eksistensi perumahan/permukiman yang dimulai dengan kedatangan sekelompok etnis tertentu pada suatu lokasi, baik di tepi air maupun di atas badan air (perairan), yang kemudian menetap dan berkembang secara turun-temurun membentuk suatu klan dan komunitas tertentu. Keberadaan kelompok masyarakat (komunitas) di lokasi tersebut cenderung bersifat sangat homogen dan mengembangkan suatu tradisi dan nilai-nilai tertentu dalam kehidupannya. Pada perkembangan selanjutnya, sifat tersebut menjadi karakter dan ciri khas permukiman tersebut, seperti : Suku Laut di Riau, Suku Bajo di Wajo, Banggai/Luwuk, Labuan Bajo, Kendari dan Bajo-e (Kota Watampone - Sulsel). Dapat dikatakan, bahwa eksistensi komunitas dan perumahan ini lebih didasarkan faktor budaya dan tradisi, bukan didasari oleh keterbatasan lahan/tanah di darat dan/atau sekedar alasan praktis memperoleh tempat tinggal.

b. Eksistensi sebagai daerah alternatif perumahan/permukiman (marginal), yang terjadi karena adanya peningkatan arus urbanisasi. Perkembangan ini mengakibatkan perumahan di tepi air maupun atas air ini menjadi kawasan liar dan kumuh perkotaan, seperti di Sumatera Utara (Jermal dan sekitarnya), Palangkaraya (Danau Seha dan sekitarnya), Ujung Pandang (Mariso, Tanjung Bunga dan Tallo), Balikpapan (Kampung Baru), dll. Dapat dikatakan, bahwa eksistensi komunitas dan perumahan ini lebih didasari oleh keterbatasan lahan/tanah di darat dan/atau sekedar alasan praktis memperoleh tempat tinggal (mudah dan murah), yang tidak berbeda dengan permukiman di bantaran sungai atau di sekitar rel KA.

\subsection{Parameter Kekuatan Material Kayu}

Keandalan jenis kayu ULIN sebagai meterial tiang rumah tradisional suku Bugis Makassar, diduga adalah disebabkan oleh dua faktor, yakni :

1. Unsur kimia dalam serat kayu ULIN mengalami proses pengawetan (preservation) bila terbenam di dalam air laut. Hal ini dimungkinkan bila jenis mineral kristal serat kayu akan membentuk penguatan (skeleton) bila bereaksi dengan unsur clorida dari molekul air laut.

2. Karakteristik berat jenis kayu ULIN yang lebih besar dari berat jenis air laut, sehingga tidak akan mengalami gaya apung (up lift) bila ditanam ke dalam dasar laut dengan media air laut di sekelilingnya. Demikian pula dengan keandalan tiang tersebut di dalam menerima beban akibat arus air laut (dynamic force), disebabkan karena besarnya berat jenis kayu tersebut, sehingga cukup stabil menjaga keseimbangan lateral dari konstruksi secara menyeluruh (global). Sedangkan kemampuan kayu ULIN 
memikul beban superstruktur disebabkan kekuatan serat kayu, baik tekan, tekuk, dan kekuatan lentur yang cukup tinggi.

Hipotesis pertama tidak akan dilakukan pengujian, karena peluang untuk mempertahankan material kayu ULIN sebagai elemen tiang rumah suku Bugis Makassar, mengingat keberadaan bahan kayu tersebut sudah semakin langka, sulit, dan mengancam kelestariannya di alam, bila terus menerus dieksploitasi.

Sedangkan hipotesis kedua akan dielaborasi secara optimal, guna menjadi acuan selanjutnya di dalam mencari, merekayasa, dan menemukan material alternatif untuk elemen tiang rumah suku Bugis Makassar sebagai pengganti material kayu ULIN tersebut.

Untuk itu maka diperlukan pengujian laboratorium terhadap material kayu ULIN yang terdiri atas:

1. Pengujian sifat-sifat kayu (Wood Properties Test)

- Uji Berat Volume Kayu

- Uji Absorpsi Kayu

2. Pengujian Kekuatan Kayu (Wood Strength Test)

- Uji Kuat Tekan Sejajar Serat

- Uji Kuat Tekan Tegak Lurus Serat

- Uji Kuat Tarik Sejajar Serat

- Uji Kuat Tarik Tegak Lurus Serat

- Uji Kuat Geser

Untuk pengujian sifat-sifat kayu diperlukan data pengujian kurang lebih sebanyak 12 sample, dengan assumsi bahwa dengan jumlah data sebanyak itu sudah akan mampu memberikan data dengan validitas yang memadai untuk mendapatkan nilai berat volume kayu dan nilai absorpsi dari material kayu ULIN.

Sedangkan untuk pengujian kekuatan kayu, dibutuhkan pengujian minimal 12 sample, dengan assumsi bahwa kondisi serat kayu ULIN yang cukup variatif sehingga membutuhkan sajian data yang lebih banyak untuk mendapatkan gambaran kekuatan kayu yang cukup, baik terhadap kekuatan tekan, tarik, dan geser.

Sifat dasar kayu sebagai material yang sangat lentur (very flexible), menjadikannya sebagai material yang paling handal dalam menerima beban dinamis. Oleh karena itu teori untuk menganalisis respon dan efek beban dinamis pada kayu tidak bisa menggunakan analogi dengan teori-teori yang dikembangkan dari hasil penelitian terhadap bangunan beton dan/atau bangunan baja. Kelenturan kayu jauh lebih besar dibanding bahan beton atau baja, sehingga tidak tepat bila identifikasi kerusakan elemen struktur dari kayu, menggunakan teori yang dikembangkan dari hasil pengujian material lain. Untuk menggambarkan perbedaan sifat material dalam menerima beban dapat diperlihatkan dengan grafik di bawah ini :
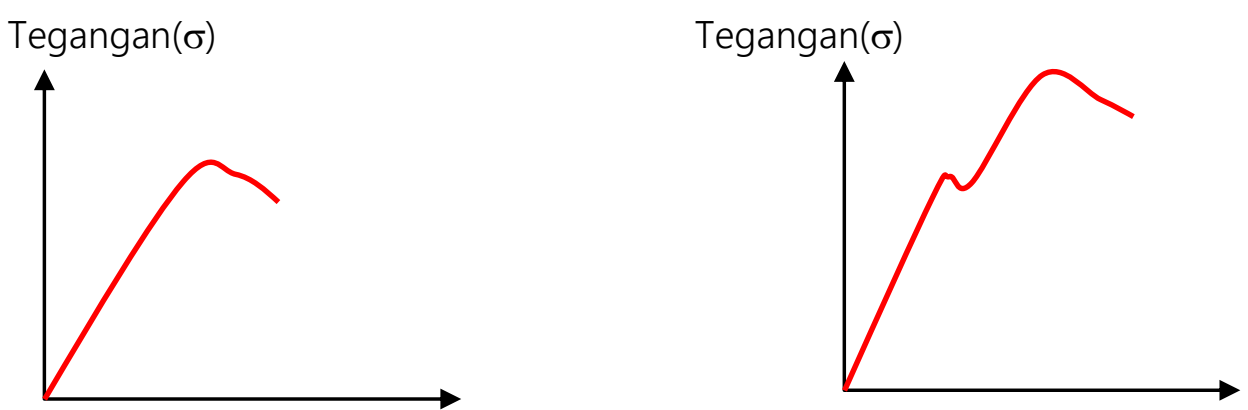

(a) Hubungan $\boldsymbol{\sigma}-\boldsymbol{\varepsilon}$ pada Beton
(b) Hubungan $\sigma^{-\varepsilon}$ pada Baja

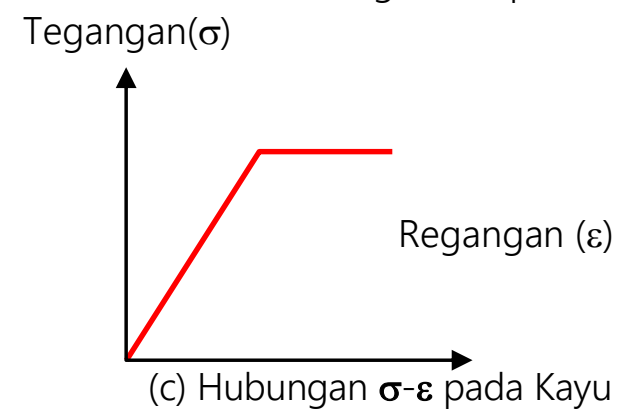

Gambar 2. Hubungan Tegangan-Regangan pada material bangunan

\section{METODE PENELITIAN}

\subsection{Jenis dan Desain Penelitian}

Pada dasarnya penelitian ini merupakan penelitian deskriptif yang bertujuan untuk memberikan gambaran secara sistematis dan obyektif mengenai bentuk existing dari system konstruksi setiap elemen superstruktur dan rangka kuda-kuda pada rumah tradisional suku Bugis Makassar. Kemudian selanjutnya akan dielaborasi kelemahan dan kelebihan dari setiap elemen struktur tersebut, sekaligus akan dijabarkan usulan system konstruksi yang memiliki potensi kekokohan dan nilai estetika yang lebih baik dan lebih relevan dengan nilai-nilai kultur masyarakat suku Bugis Makassar.

Selanjutnya untuk menghasilkan data tentang karaktersitik teknis dari elemen tiang/kaki rumah tradisional suku Bugis Makassar, dilakukan pengujian Laboratorium terhadap material kayu spesifik yang oleh masyarakat setempat disebut kayu ULIN. Uraian terhadap karakteristik teknis ini akan didiskripsikan dalam bentuk tabulasi dari hasil analisis statistik terhadap hasil pengujian laboratorium tersebut.

\subsection{Metode Pengujian Bahan}

Penelitian dan pengujian bahan tiang/kaki ini menggunakan metode diskriptif analisis terhadap kekuatan bahan, dengan menggunakan standar pengujian SNI-2002, dengan jenis uji material yang meliputi :

a. Uji berat volume kayu

b. Uji absorpsi kayu

c. Uji kekuatan tekan ; sejajar dan tegak lurus arah serat kayu.

d. Uji kekuatan tarik; sejajar dan tegak lurus arah serat kayu.

e. Uji kekuatan lentur kayu

f. Uji kekuatan geser kayu

Pengumpulan data dengan tes langsung menggunakan alat dan bahan uji sebagai sampel. Model struktur diambil dari analisis terhadap beberapa model rumah 
tradisional/vernakular yang ada di kampung Bugis Makassar. Hasil pengujian bahan akan digunakan untuk menganalisis kekuatan bahan dengan menggunakan beberapa formula sebagai alat bantu penilaian.

\subsection{Teknik Pengumpulan dan Analisis Data}

\section{Teknik Pengumpulan Data}

Penelitian ini menggunakan metode phenomenologi/naturalistik, pengambilan Informasi tentang typical struktur original dari rumah tradisional suku Bugis Makassar secara purposive atau sampel diambil oleh peneliti dengan tujuan tertentu. Tujuan tertentu yang dimaksud adalah sampel tersebut dapat mewakili populasi dan informasi lain yang ada dalam keseluruhan populasi penelitian yang diteliti. Menurut Marzuki (2000:50-51) pengambilan sampel dengan cara purposive ini dengan syarat sampel harus merupakan representasi dari populasi. Metode pengambilan sampel secara purposive ini diterapkan dalam memilih :

a. Sampel kayu ULIN sebagai material tiang/kaki pada rumah tradisional suku Bugis Makassar, yang akan diuji secara teknis di laboratorium untuk mendapatkan sifat-sifat teknis dari kayu tersebut.

b. Teks lama, hasil penelitian atau pandangan tertulis dari para pakar mengenai arsitektur Rumah Tradisional Bugis Makassar atau pemikiran-pemikiran yang berkaitan, yang mempengaruhi arsitektur Suku Bugis Makassar serta peta-peta lokasi.

c. Obyek-obyek yang diamati dan tokoh masyarakat yang diwawancarai.

d. Artefak yang berupa rumah-rumah tinggal di kampung Bugis Makassar di perairan.

2. Teknik Analisis Data

Analisis data yang digunakan dalam penelitian ini terdiri atas Metode Analisis Kualitatif dan Metode Analisis Kuantitatif. Telaah dan evaluasi bentuk konstruksi elemen superstruktur dan kuda-kuda, merupakan diskripsi analisis kualitatif. Sedangkan data hasil pengujian laboratorium akan dianalisis dengan metode kuantitatif, yaitu analisis statitik.

\section{HASIL YANG DICAPAI}

4.1. Gambaran Umum dan Lokasi Penelitian

Kota Makassar terletak di pesisir pantai mempunyai peranan yang sangat vital, baik yang sifatnya lokal, regional, nasional dan internasional. Keberadaan fungsi, peranan dan kedudukan tersebut, menjadikan Kota Makassar mengalami pertumbuhan dan perkembangan yang pesat dalam dasawarsa terakhir ini. Terutama semenjak dibukanya jalur-jalur khusus regional dan internasional, serta dengan dukungan sarana dan prasarana yang baik sehingga membuat akses dari dan ke Makassar menjadi lancar. Kota Makassar juga merupakan pintu gerbang perekonomian yang sekaligus menjadi pusat pengembangan industri di Indonesia bagian Timur dengan konsentrasi penyebaran penduduk yang relatif pada beberapa wilayah kecamatan yang ada dikota ini, dengan berbagai aktivitas seperti aktivitas dibidang perekonomian, perdagangan, pendidikan, kesehatan, militer, wisata, hiburan dan lain sebagainya. Kota Makassar mempunyai batas-batas administratif sebagai berikut:

a) Sebelah Selatan berbatasan dengan Kabupaten Gowa

b) Sebelah Utara berbatasan dengan Kabupaten Maros 
c) Sebelah Timur berbatasan dengan Kabupaten Maros

d) Sebelah Barat berbatasan dengan Selat Makassar.

Kota Makassar yang memiliki luas wilayah areal $\pm 175,77 \mathrm{Km}$ persegi atau 0,28 \% dari luas Provinsi Sulawesi Selatan yang terbagi dalam 14 kecamatan dan 96 kelurahan. Kota Makassar cukup unik dengan bentuk menyudut di bagian Utara, sehingga mencapai dua sisi pantai yang saling tegak lurus di bagian Utara dan Barat. Di sebelah Utara kawasan pelabuhan hingga Tallo telah berkembang kawasan campuran termasuk di dalamnya armada angkutan laut, perdagangan, pelabuhan rakyat dan samudera, Sebagai rawa-rawa, tambak, dan empang dengan perumahan kumuh hingga sedang. Kawasan pesisir dari arah Tengah ke bagian Selatan berkembang menjadi pusat kota (Centre Busines District - CBD) dengan fasilitas perdagangan, pendidikan, pemukiman, fasilitas rekreasi dan resort yang menempati pesisir pantai membelakangi laut yang menggunakan lahan hasil reklamasi pantai.

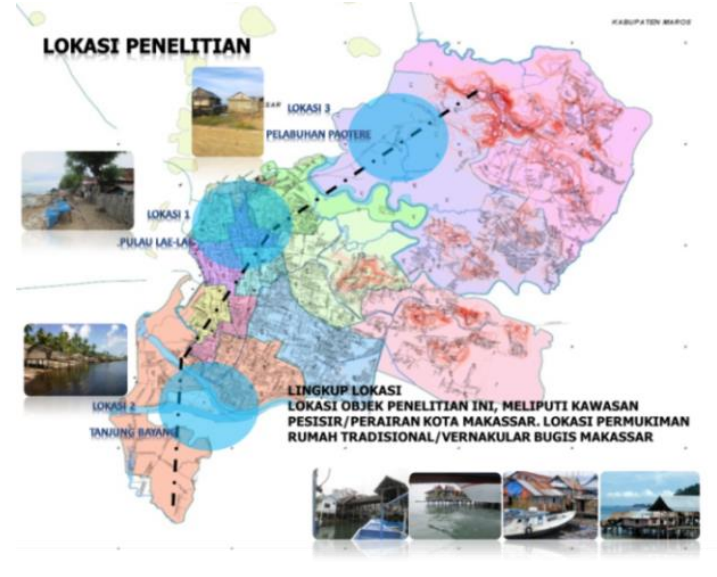

Gambar 3. Peta Lokasi Penelitian Kawasan Kota Makassar

a. Keadaan Topografi

Keadaan tofografi wilayah Kota Makassar berdasarkan sumber data yang diperoleh berada pada ketinggian 0 sampai $15 \mathrm{M}$ dari permukaan air laut, dan berada pada kisaran lereng 2-18\%. Selanjutnya berdasarkan kondisi tersebut, keadaan iklim Kota Makassar termasuk kategori iklim tropis, temperatur rata-rata harian berkisar antara $24,5^{\circ} \mathrm{C}-31,8^{\circ} \mathrm{C}$.

b. Keadaan Geologi

Keadaan geologi Kota Makassar berdasarkan data yang diperoleh terdiri atas; relief kasar yang merupakan morfologi daratan, sungai, dan pantai. Morfologi yang menonjol di Kota Makassar adalah kerucut gunung api Lompobattang, gunung Batu Rape dan gunung Cindako. Morfologi tersebut tersusun oleh batuan gunung api berumur pliosen atau kurang lebih 5 juta tahun lalu (gunung Baturape/Cindako), dan berumur plistosen atau kurang lebih 1,8 juta tahun (formasi Lompobattang).

c. Hidrologi

Keadaan hidrologi Kota Makassar, berdasarkan hasil observasi lapangan yang dilakukan ditemukan daerah-daerah kawasan kota yang mengalami genangan periodik. 
Sumber air permukaan berasal dari sungai Jeneberang dan sungai Tallo. Pada kondisi tertentu terutama pada saat musim hujan sungai tersebut mempengaruhi sebahagian wilayah Kota Makassar. Sungai Jeneberang dan Sungai Tallo di identifikasi merupakan ancaman banjir perkotaan.

d. Jenis Tanah

Jenis tanah yang terdapat di Kota Makassar antara lain jenis tanah Aluvial, penyebarannya disepanjang pantai, membujur dari Kecamatan Tamalate, Mariso, Ujung Pandang, Wajo, Ujung Tanah, Tallo dan Biringkanaya dengan tingkat kedalaman efektif tanah antara 20-40 cm memiliki tekstur tanah sedang sampai halus, secara umum lokasi di daerah pinggiran Kota Makassar saat ini dimanfaatkan masyarakat untuk kegiatan pertanian dan perkebunan.

e. Tata Guna Lahan

Kondisi tata guna lahan Kota Makassar secara umum terdiri atas; permukiman dan bangunan lainnya (perkantoran, perumahan dan permukiman, pendidikan, jasa, fasilitas sosial), sawah tadah hujan, dan lahan yang tidak diusahakan atau lahan kosong. Pergesaran pemanfaatan lahan kawasan Kota Makassar secara umum telah mengalami perubahan yang cukup drastis, akibat terjadinya peningkatan pembangunan aktivitas sosial ekonomi.

\subsection{Hasil Pengamatan Lapangan}

Beberapa variabel penelitian ini yang dilakukan melalui pengamatan langsung di lapangan, dan dilanjutkan dengan kajian dan analisis kualitatif. Variabel penelitian yang dikumpulkan berdasarkan pengamatan langsung di lapangan yakni:

a. Lokasi permukiman; yang meliputi aspek keamanan terhadap arus dan gelombang laut, serta keamanan terhadap angin, juga dilakukan pengamatan terhadap kondisi dasar perairan pada wilayah permukiman.

b. Typical konstruksi rumah tradisional suku Bugis Makassar ; yang meliputi bentuk struktur dan sistem sambungan pada elemen tiang/kaki, gelagar, superstruktur, dan kuda-kuda.

c. Kondisi dan potensi bahan kayu Ulin sebagai material tiang/kaki rumah

Bugis Makassar.

Hasil pengamatan lapangan terhadap berbagai aspek tersebut di atas, dapat dipaparkan beberapa data actual seperti terlihat pada Tabel 1.

\subsection{Hasil Pengujian Laboratorium}

Beberapa variabel teknis yang menjadi perhatian di dalam penelitian ini, adalah didasarkan pada parameter kayu Ulin sebagai elemen tiang/kaki rumah di atas perairan yang telah terbukti kehandalannya dipergunakan oleh masyarakat selama ini. Identifikasi variable kayu Ulin ini, dimaksudkan untuk menjadi referensi dalam mengembangkan inovasi riset guna menemukan material alternative pengganti kayu Ulin. Parameter kayu Ulin yang diuji di laboratorium meliputi :
a. Uji berat volume kayu
b. Uji absorpsi kayu
c. Uji kekuatan tekan; sejajar dan tegak lurus arah serat kayu.
d. Uji kekuatan tarik; sejajar dan tegak lurus arah serat kayu. 
e. Uji kekuatan lentur kayu

f. Uji kekuatan geser kayu

Dari pengujian keenam parameter tersebut, dapat dilihat beberapa fenomena yang bersifat keunikan, yang cukup significant terhadap strength dan durability dari kayu Ulin yang telah terbukti cukup handal sebagai elemen tiang/kaki rumah di atas perairan. Hasil pengujian kayu Ulin di laboratorium disajikan dalam Tabel 2.

Tabel 1. Hasil Pengamatan Lapangan

\begin{tabular}{|c|c|c|c|c|}
\hline No & Aspek yang diamati & Kondisi Aktual & Analisis \& Diskusi & Dokumentasi Aktual \\
\hline 1 & $\begin{array}{l}\text { Keamanan } \\
\text { permukiman } \\
\text { terhadap arus \& } \\
\text { gelombang }\end{array}$ & $\begin{array}{l}\text { Lokasi permukiman } \\
\text { terlindung di dalam } \\
\text { teluk tertutup, yang } \\
\text { mana tanjung Bungan } \\
\text { menjadi break water } \\
\text { yang alami. }\end{array}$ & $\begin{array}{l}\text { Konstruksi sederhana } \\
\text { rumah tradisional } \\
\text { nelayan cukup aman } \\
\text { dari ancaman arus } \\
\text { dan gelombang laut. }\end{array}$ & \\
\hline 2 & $\begin{array}{l}\text { Keamanan } \\
\text { permukiman } \\
\text { terhadap angin }\end{array}$ & $\begin{array}{l}\text { Lokasi permukiman } \\
\text { berada sepanjang } \\
\text { pesisir Kota Makassar, } \\
\text { sehingga angin barat } \\
\text { akan bergerak jauh di } \\
\text { atas permukaan laut. }\end{array}$ & $\begin{array}{l}\text { Elemen bangunan } \\
\text { rumah terutama atap } \\
\text { rumah yang sangat } \\
\text { sederhana, cukup aman } \\
\text { dari hempasan angin. }\end{array}$ & \\
\hline 3 & $\begin{array}{l}\text { Stabilitas tiang/kaki } \\
\text { rumah berdiri di atas } \\
\text { lapis tanah dasar } \\
\text { perairan }\end{array}$ & $\begin{array}{l}\text { Jenis tanah dasar } \\
\text { perairan adalah "marine } \\
\text { silty clay". }\end{array}$ & $\begin{array}{l}\text { Marine silty clay } \\
\text { memiliki plastisitas yang } \\
\text { cukup baik, sehingga } \\
\text { friction bearing pada } \\
\text { tiang rumah cukup baik. }\end{array}$ & \\
\hline 4 & $\begin{array}{l}\text { Bentuk sambungan } \\
\text { antara kaki dengan } \\
\text { gelagar rumah }\end{array}$ & $\begin{array}{l}\text { Sambungan cukup } \\
\text { sederhana dengan } \\
\text { perletakan langsung } \\
\text { gelagar pada } \\
\text { pencabangan elemen } \\
\text { tiang/kaki. }\end{array}$ & $\begin{array}{l}\text { Bentuk sambungan } \\
\text { adalah "Rol", yang tidak } \\
\text { memiliki kekakuan } \\
\text { terhadap gaya lateral } \\
\text { (gelombang, angin) }\end{array}$ & \\
\hline 5 & $\begin{array}{l}\text { Bentuk struktur } \\
\text { bangunan atas }\end{array}$ & $\begin{array}{l}\text { Bangunan atas } \\
\text { tersambung pada } \\
\text { elemen gelagar dengan } \\
\text { sambungan pasak }\end{array}$ & $\begin{array}{l}\text { Konstruksi bangunan } \\
\text { atas didominasi sistem } \\
\text { struktur batang tekan, } \\
\text { sehingga diperlukan } \\
\text { perkuatan batang tarik } \\
\text { dalam struktur ruang }\end{array}$ & \\
\hline
\end{tabular}




\begin{tabular}{|c|c|c|c|c|}
\hline 6 & $\begin{array}{l}\text { Bentuk struktur } \\
\text { rangka kuda-kuda }\end{array}$ & $\begin{array}{l}\text { Kuda-kuda berbentuk } \\
\text { pelana sederhana. }\end{array}$ & $\begin{array}{l}\text { Bentuk kuda-kuda yang } \\
\text { ada merupakan bentuk } \\
\text { serapan dari kuda-kuda } \\
\text { colonial Belanda, dan } \\
\text { sudah bergeser jauh } \\
\text { dari bentuk aslinya }\end{array}$ & 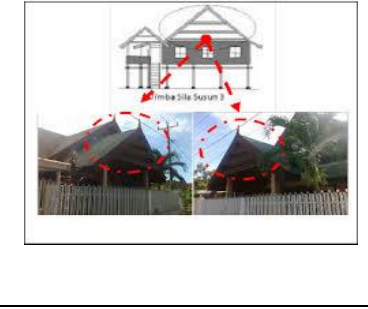 \\
\hline 7 & $\begin{array}{l}\text { Eksistensi kayu } \\
\text { Ulin/Sappu }\end{array}$ & $\begin{array}{l}\text { Kayu Ulin atau Sappu } \\
\text { adalah jenis tumbuhan } \\
\text { langka, dan populasi } \\
\text { sudah terbatas }\end{array}$ & $\begin{array}{l}\text { Diperlukan material } \\
\text { inovasi untuk elemen } \\
\text { tiang/kaki rumah } \\
\text { sebagai pengganti kayu } \\
\text { Ulin/Sappu, dengan } \\
\text { strength \& durability } \\
\text { yang mendekati kayu } \\
\text { Ulin/Sappu. }\end{array}$ & 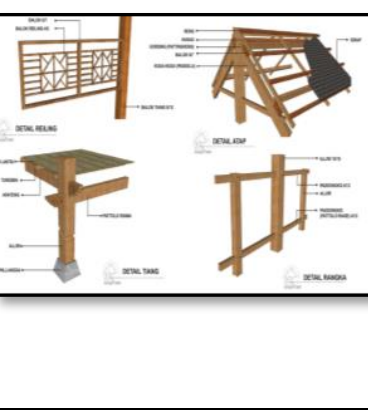 \\
\hline
\end{tabular}

Tabel 2. Parameter Fisis dan Teknis Kayu ULIN (Hasil Uji Laboratorium)

\begin{tabular}{|c|c|c|c|c|c|}
\hline No & Parameter & $\begin{array}{c}\text { Nilai Uji } \\
\text { Laboratorium }\end{array}$ & Konversi & $\begin{array}{c}\text { Batasan } \\
\text { Kayu Kls-I }\end{array}$ & Keterangan \\
\hline 1 & $\begin{array}{l}\text { Berat } \\
\text { Volume }\end{array}$ & $1,21 \mathrm{gr} / \mathrm{cm}^{3}$ & $1.210 \mathrm{~kg} / \mathrm{m}^{3}$ & $\geq 900 \mathrm{~kg} / \mathrm{m}^{3}$ & tenggelam \\
\hline 2 & $\begin{array}{l}\text { Absorpsi } \\
\text { Alami }\end{array}$ & $10,21 \%$ & - & - & durability tinggi \\
\hline 3 & $\begin{array}{l}\text { Absorpsi } \\
\text { Max }\end{array}$ & $39,82 \%$ & - & - & durability tinggi \\
\hline 4 & Kuat Tarik $\perp$ & $1,00 \mathrm{~N} / \mathrm{mm}^{2}$ & $10,22 \mathrm{~kg} / \mathrm{cm}^{2}$ & - & - \\
\hline 5 & Kuat Tarik // & $64,50 \mathrm{~N} / \mathrm{mm}^{2}$ & $\begin{array}{l}657,49 \\
\mathrm{~kg} / \mathrm{cm}^{2}\end{array}$ & $\geq 650 \mathrm{~kg} / \mathrm{m}^{2}$ & $\sigma_{\mathrm{tr}-\mathrm{izin}}=130 \mathrm{~kg} / \mathrm{cm}^{2}$ \\
\hline 6 & $\begin{array}{l}\text { Kuat Tekan } \\
\perp\end{array}$ & $66,08 \mathrm{~N} / \mathrm{mm}^{2}$ & $\begin{array}{l}673,63 \\
\mathrm{~kg} / \mathrm{cm}^{2}\end{array}$ & - & $\sigma_{\text {tk-izin }}=40 \mathrm{~kg} / \mathrm{cm}^{2}$ \\
\hline 7 & $\begin{array}{l}\text { Kuat Tekan } \\
\text { // }\end{array}$ & $66,72 \mathrm{~N} / \mathrm{mm}^{2}$ & $\begin{array}{l}680,14 \\
\mathrm{~kg} / \mathrm{cm}^{2}\end{array}$ & $\geq 650 \mathrm{~kg} / \mathrm{m}^{2}$ & $\sigma_{\text {tk-izin }}=130 \mathrm{~kg} / \mathrm{cm}^{2}$ \\
\hline 8 & Kuat Geser & $15,50 \mathrm{~N} / \mathrm{mm}^{2}$ & $157,99 \mathrm{~kg} / \mathrm{cm}^{2}$ & $2 \geq 125 \mathrm{~kg} / \mathrm{m}^{2}$ & $\tau_{\text {izin }}=20 \mathrm{~kg} / \mathrm{cm}^{2}$ \\
\hline 9 & Kuat Lentur & $55,70 \mathrm{~N} / \mathrm{mm}^{2}$ & $\begin{array}{l}567,74 \\
\mathrm{~kg} / \mathrm{cm}^{2}\end{array}$ & $\geq 1100 \mathrm{~kg} / \mathrm{m}^{2}$ & $\sigma_{\mathrm{It}-\mathrm{zin}}=150 \mathrm{~kg} / \mathrm{cm}^{2}$ \\
\hline
\end{tabular}

4.4. Pembahasan Hasil Penelitian

Dari rangkaian data hasil penelitian, baik yang merupakan hasil pengamatan langsung di lapangan, maupun hasil pengujian material di laboratorium, maka dapat didiskusikan dan dianalisis beberapa fenomena riset yang menarik, antara lain: 


\subsubsection{Aspek konstruksi rumah Tradisional Bugis Makassar}

Secara umum bentuk konstruksi rumah tradisional yang ada sekarang "sangat sederhana" dan banyak yang kurang sesuai dengan kaidah statika struktur. Beberapa aspek yang menjadi perhatian dalam pengamatan yang dilakukan di lapangan, antara lain:

a. Sistem sambungan kaki dengan gelagar yang berbentuk "rol", tidak memberikan kekakuan dan kekokohan terhadap struktur secara keseluruhan. Kelemahan ini dapat diatasi dengan membuat sistem sambungan antara kaki dengan gelagar yang relative lebih kaku, dengan sambungan "sendi". Sambungan sendi antara kaki-gelagar memanjang-gelagar memanjang, dapat dibuat dengan penggunaan topi tiang (pile cap) di atas kaki, yang dilengkapi dengan takikan pada kedua arah gelagar, sehingga gelagar gelagar tersebut terkait satu sama lain di dalam topi tiang. Untuk menggambarkan bentuk sambungan antara kaki dengan gelagar yang memberikan perletakan sendi, dapat dilihat pada gambar detail berikut ini :

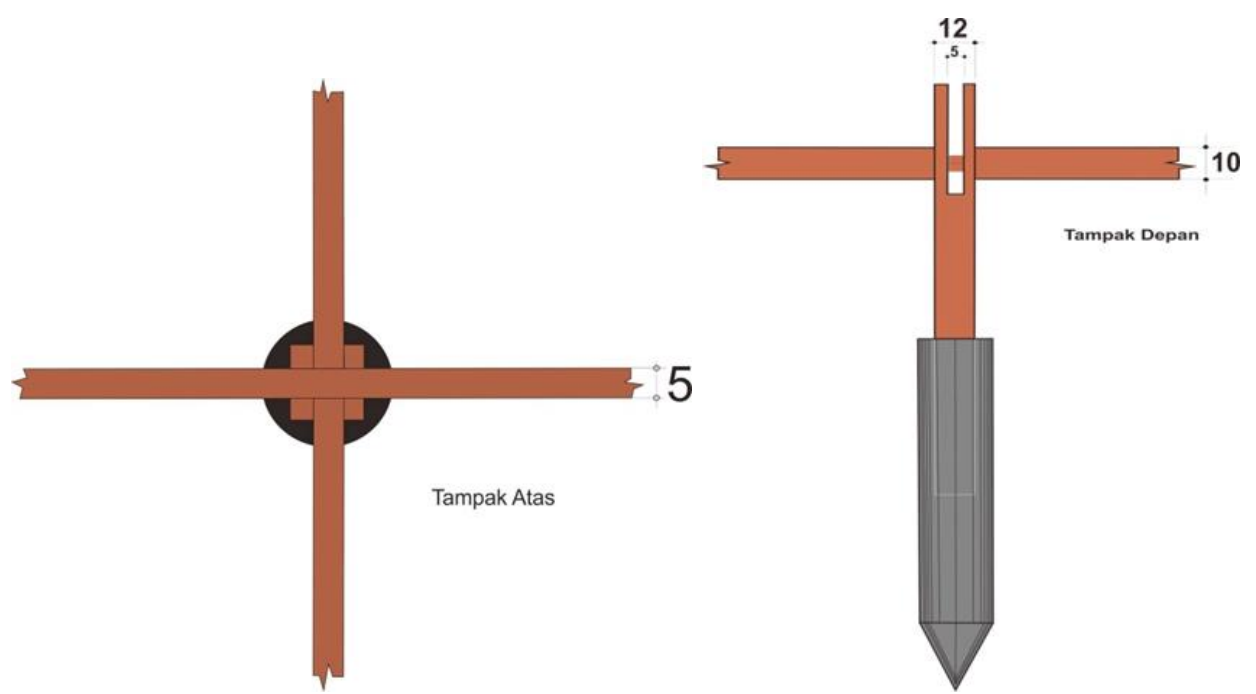




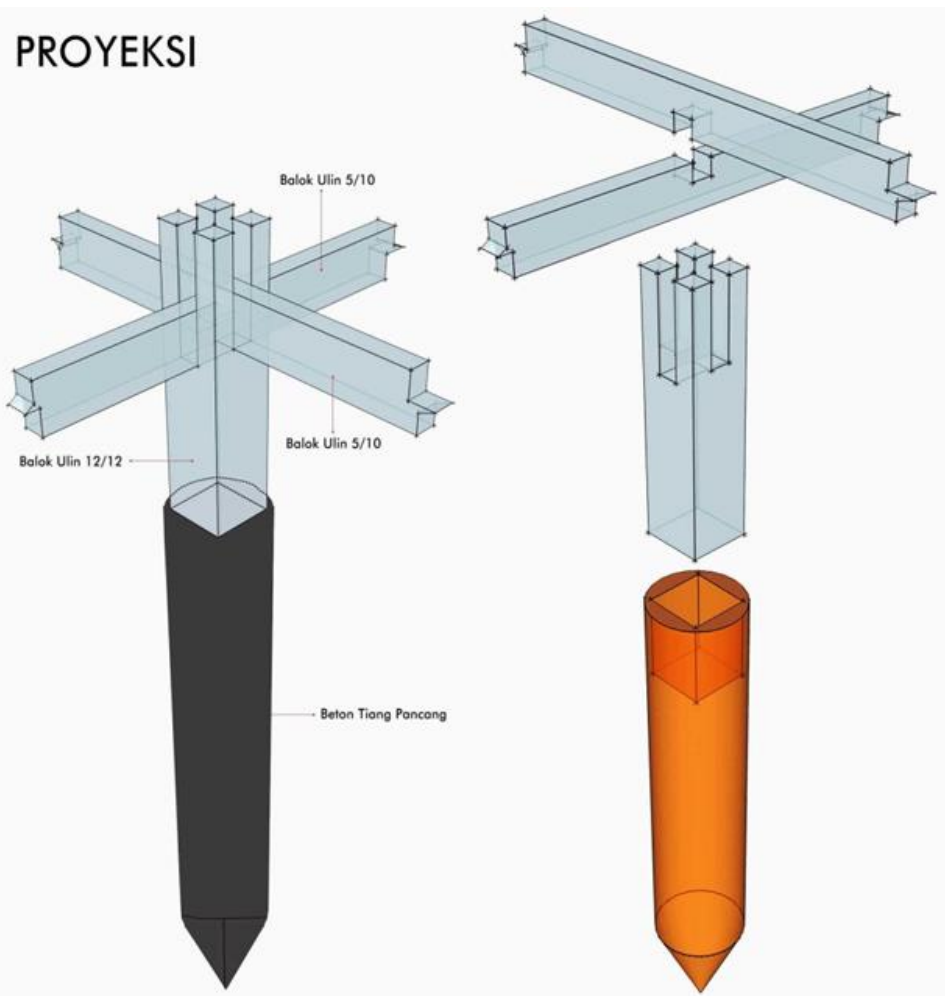

Gambar 4. Detail sambungan kaki dengan gelagar

Dengan sistem sambungan takik langsung pada kedua gelagar (melintang dan memanjang) dalam jepitan pile cap, akan menimbulkan sambungan yang lebih kaku dalam bentuk sendi. Takikan yang relative tipis dan jepitan pile cap, tidak akan menimbulkan perlemahan pada balok gelagar akibat takikan.

b. Struktur bangunan atas didominasi dengan sistem struktur batang tekan. Bila diinginkan stabilitas konstruksi bangunan atas diperlukan perkuatan batang tarik dalam struktur ruang. Elemen batang tarik sangat urgen pada bangunan atas adalah pasak pada bagian bawah tiang atas. Hal ini sangat diperlukan karena tiang atas tidak terpasak oleh gelagar, sehingga untuk mengakukan tiang atas diperlukan pasak pada bagian bawah. Dengan demikian gaya tarik akibat pergoyangan tiang dapat dipikul oleh pasak bawah sebagai batang tarik.

c. Bentuk kuda-kuda pelana sederhana, yang merupakan bentuk serapan dari kuda-kuda kolonial Belanda, dan sudah bergeser jauh dari bentuk aslinya. Bentuk atap bangunan adalah berbentuk kerucut. Secara alami bentuk atap kerucut akan memberikan suku ruang dalam rumah yang lebih segar dibandingkan dengan bentuk atap pelana dengan ketinggian atap yang sangat minim seperti yang ada pada rumah dewasa ini. Untuk memberikan kondisi suhu yang lebih segar dalam ruang rumah perlu dipikirkan untuk menggunakan kembali falsafah atap kerucut yang dimiliki masyarakat Bugis Makassar, yang dimodifikasi sesuai perkembangan masyarakat sekarang ini. Untuk memberikan gambaran atas usulan bentuk atap yang dapat memberikan suhu yang lebih segar dalam rumah, dapat disimak pada gambar berikut: 

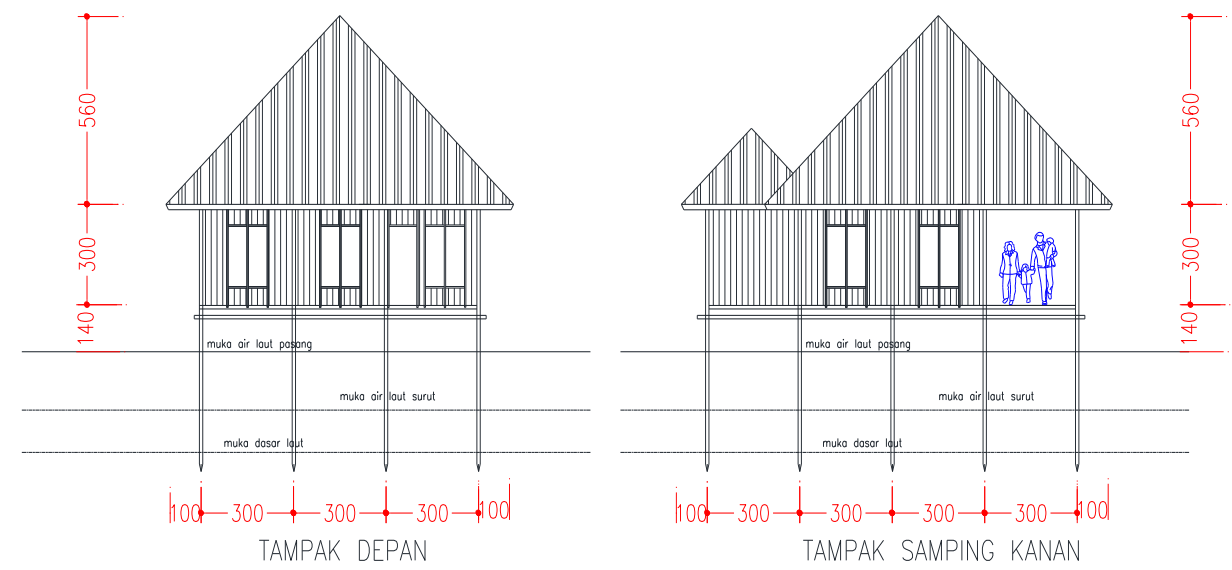

\subsubsection{Sifat-sifat fisis kayu Ulin}

Parameter sifat-sifat fisis kayu Ulin yang terungkap dari hasil pengujian di laboratorium yang dilaksanakan dalam penelitian ini adalah sebagai berikut:

1. Berat volume sebesar $1,21 \mathrm{gr} / \mathrm{cm}^{3}$, suatu nilai berat volume yang jauh berada di atas batasan berat volume kayu kelas I $\left(\geq 900 \mathrm{~kg} / \mathrm{cm}^{3}\right)$. Dengan sifat berat volume kayu Ulin yang lebih besar dari berat jenis air ini membuat kayu Ulin tenggelam di dalam air, sehingga kayu tersebut tidak akan mengalami gaya apung (up lift) bila berada di dalam air. Oleh karena itu stabilitas kayu Ulin terhadap gerakan arus dan gelombang air laut cukup baik, bila dibandingkan dengan jenis kayu yang terapung di dalam air. Disamping itu dengan berat volume yang ideal semacam itu pula mengakibatkan kayu Ulin yang dipancang ke dalam lapisan tanah lunak tidak akan mengalami self deformation akibat berat sendiri yang dimilikinya. Hal ini berbeda pada beton massif yang dipancang pada lapisan tanah lunak, apabila daya dukung skin friction lebih kecil dari berat sendiri beton, maka tiang beton akan mengalami penurunan sendiri (self deformation) yang biasa berlangsung dalam jangka panjang (long term).

2. Absorpsi kayu Ulin. Dari hasil pengujian laboratorium didapatkan informasi bahwa kayu Ulin dalam kondisi kering udara bebas, ketika dimasukkan dalam air dalam jangka panjang hanya memiliki absorpsi terhadap air sebesar 10,21\%. Sedangkan kayu yang dikeringkan dengan oven, ketika dimasukkan dalam air dalam jangka panjang memiliki absorpsi terhadap air sebesar 39,82\%. Hal ini memperlihatkan bahwa kerapatan serat kayu Ulin sangat tinggi dibandingkan dengan kayu jenis yang lainnya. Diduga mungkin dengan sifat kerapatan serat semacam ini yang mengakibatkan jenis kayu Ulin memiliki keawetan (durability) yang cukup baik, sehingga dapat bertahan lama di dalam air. Disamping itu kemungkinan adanya enzim kimia yang terkandung dalam material kayu Ulin dapat pula menjadi factor pendukung terhadap keawetan dari kayu Ulin tersebut, yang mungkin menarik untuk diteliti oleh para ahli biokimia tumbuhan.

\section{KESIMPULAN DAN SARAN}

Dari analisis dan pembahasan terhadap data yang telah dihasilkan dari kegiatan penelitian ini, maka dikemukakan kesimpulan dan saran sebagai berikut: 


\subsection{Kesimpulan}

a. Dari aspek geografi dan geologis lokasi permukiman Bugis Makassar cukup aman, baik dari arus dan gelombang air laut; dari lintasan angin taifun ; maupun stabilitas tiang/kaki rumah yang berdiri di atas lapisan tanah dasar perairan.

b. Dari aspek konstruksi rumah tradisional Bugis Makassar, perlu perbaikan bentuk pada beberapa komponen, antara lain ; struktur sambungan antara tiang dengan gelagar yang sebaiknya dibuat dalam bentuk "sendi"; bangunan atas yang memerlukan batang tarik berupa pasak bawah pada tiang ; dan bentuk atap rumah yang perlu kembali mengelaborasi bentuk atap kerucut seperti bentuk atap pada bangunan Rumah Tradisional.

c. Karakteristik kayu Ulin yang dihasilkan dari pengujian laboratorium sangat menguatkan bukti empiris yang dimiliki oleh masyarakat Bugis Makassar, bahwa kayu Ulin merupakan material yang sangat handal untuk dipergunakan sebagai tiang rumah di zone perairan. Permasalahannya bahwa kayu Ulin merupakan tumbuhan yang sudah diambang kepunahan akibat eksplotasi untuk berbagai kepentingan masyarakat setempat.

5.2. Saran/rekomendasi

a. Bentuk-bentuk struktur bangunan rumah tradisional Bugis Makassar, perlu dilakukan perbaikan yang meliputi: sistem sambungan antara tiang/kaki dengan gelagar, elemen pasak tarik pada tiang bangunan atas, dan juga pada bentuk atap perlu perbaikan dalam hal sambungan.

b. Diperlukan inovasi baru untuk menemukan material alternative sebagai pengganti kayu Ulin untuk elemen tiang/kaki pada rumah Bugis Makassar dan rumah - rumah lain di sekitar kawasan perairan Kota Makassar. Material alternative tersebut harus memiliki kekuatan dan keawetan yang mendekati karakteristik yang dimiliki oleh kayu Ulin, baik parameter fisis seperti berat volume dan absorpsi, maupun parameter mekanis seperti kekuatan tarik, tekan, geser dan kekuatan lenturnya.

\section{DAFTAR PUSTAKA}

1. Anonimus. 1961. Peraturan Konstruksi Kayu Indonesia $\mathrm{NI}-5$.

2. Anonimus. 1985. Annual Book of ASTM Standards, Volume 04.08-Soil and Rock.

3. Anonimus. 1985. Annual Book of ASTM Standards, Volume 04.09-Wood.

4. Blaang, Djemabut. Desember 1986. Perumahan dan Permukiman. Yayasan Obor Indonesia.

5. Budi A. Sukada. 1989. Memahami Arsitektur Tradisional dengan Pendekatan Tipologi

6. Cernica Jhon. 1995. Geotechnical Engineering and Foundation Design. Jhon Wiley and Sons Inc.

7. Daryanto. 2010. Konstruksi Kayu. Penerbit Satu Nusa.

8. Heinz Frick et.al. 2004. Ilmu Konstruksi Bangunan Kayu. Suryapranata University Press Semarang.

9. Kramadibrata Soedjono. 2002. Perencanaan Pelabuhan, Penerbit ITB.

10. Muhadjir. 2002. Pendekatan phenomenologi bersifat holistik.

11. Miles dan Huberman. 1992. Analisis Data Kualitatif. 
12. Panguriseng Darwis. 1990. Studi Pengaruh Formasi Tiang Terhadap Daya Dukung Dan Penurunan Pondasi Kelompok Tiang. Thesis Master Of Sciense Degree, Institut Teknologi Bandung.

13. Panguriseng Darwis. 1991. Studi Pengaruh Kemiringan Tiang Terhadap Daya Dukung Lateral Pada Pondasi Tiang. Penelitian Model Test pada Laboratorium Mekanika Tanah Universitas 45 Makassar.

14. Panguriseng Darwis. 1992. Kombinasi Efektip Antara Beban Vertikal Dan Beban Lateral Pada Pondasi Tiang Tunggal. Penelitian Model Test pada Laboratorium Mekanika Tanah Universitas 45 Makassar.

15. Pika. 1981. Mengenai Sifat-sifat Kayu Indonesia dan Penggunaannya. Penerbit Yayasan Kanisius Semarang.

16. Salim, Agus. 2001. Basis Kepercayaan Utama Dari Sistem Berfikir (Ontologi, Epistemologi Dan Metodologi).

17. Singarimbun, M. dan Sofyan Effendi. (edit). 1995. Metode Penelitian Survai : LP3ES.Sugiyono, 1999. Statistika untuk Penelitian. Bandung: Alfabeta

18. Sugiarto, A. 2005. Kajian Persyaratan Umum Bahan Bangunan di Indonesia. Bandung.

19. Triatmodjo Bambang. 1999. Teknik Pantai, Cetakan Pertama - Beta Offset.

20. Walter, Kaudren. 1917-1920. Structures And Settlements In Central Celebes. 